\title{
ARTICLE OPEN \\ Comparison of antibacterial activity of alexidine alone or as a final irrigant with sodium hypochlorite and chlorhexidine
}

\author{
Thaís M da Silva ${ }^{1}$, Flávio RF Alves ${ }^{2}$, Márcia TS Lutterbach ${ }^{3}$, Maurício M Paiva ${ }^{4}$ and Dennis de Carvalho Ferreira ${ }^{5}$
}

\begin{abstract}
AIMS: To compare the antibacterial activity of alexidine (ALX) alone or as a final irrigant in combination with sodium hypochlorite $(\mathrm{NaOCl})$, with the most common canal irrigants, $\mathrm{NaOCl}$ and chlorhexidine $(\mathrm{CHX})$.

MATERIALS AND METHODS: Ninety-four root fragments from extracted human teeth were infected with Enterococcus faecalis for $24 \mathrm{~h}$ and then distributed into 4 groups of 20 fragments each. The $\mathrm{NaOCl}, \mathrm{CHX}$ and ALX groups were immersed in $1 \mathrm{ml}$ of $2.5 \%$ $\mathrm{NaOCl}, 2 \% \mathrm{CHX}$, and $1 \% \mathrm{ALX}$ for $10 \mathrm{~min}$, respectively. The samples of the $\mathrm{NaOCl}+\mathrm{ALX}$ group were immersed in $1 \mathrm{ml}$ of $2.5 \% \mathrm{NaOCl}$ for $10 \mathrm{~min}$ followed by $1 \%$ ALX for $10 \mathrm{~min}$. Bacteriological samples were taken, cultured, and the colony-forming units were counted.

RESULTS: There was no significant differences among the experimental groups $(P>0.05)$ except for the comparisons $C H X$ versus $\mathrm{ALX}$ and $\mathrm{NaOCl}+\mathrm{ALX}$ versus $\mathrm{ALX}(P=0.004)$. ALX alone was the worst irrigant. $\mathrm{CHX}$ and $\mathrm{NaOCl}+\mathrm{ALX}$ eradicated all bacteria. All experimental groups were significantly more effective than the control group immersed in saline $(P<0.05)$.

CONCLUSIONS: The antibacterial effect of ALX alone was inferior to $2 \% \mathrm{CHX}$ and $2.5 \% \mathrm{NaOCl}$. However, the combination of $\mathrm{NaOCl}$ with $A L X$ as a final irrigant eradicated the biofilms.
\end{abstract}

BDJOPEN (2018) 4, 18003; doi:10.1038/bdjopen.2018.3; published online 1 June 2018

\section{INTRODUCTION}

The aim of treatment in infected root canals is to eliminate microorganisms from the root canal system and to prevent its reinfection. Bacteria are the main microorganism implicated in the apical periodontitis. ${ }^{1}$ Among them, Enterococcus faecalis deserves attention because of its high prevalence in the different types of endodontic infection, especially in persistent infections. ${ }^{2,3}$ The inherent ability of $E$. faecalis to adhere and invade dentinal tubules and form communities in an organized biofilm may contribute to its resistance to irrigant solutions and intracanal medicaments. ${ }^{4}$ Consequently, this microorganism is often chosen to induce ex vivo bacterial biofilms in assays comparing antimicrobial solutions.

During the root canal treatment, mechanical debridement is of utmost importance to remove microorganisms and organic content that might serve as nutrients for residual bacteria. Nonetheless, studies have demonstrated that although instrumentation and irrigation are effective in substantially reducing the number of bacteria in infected canals, in many cases bacteria remain in the main root canal even when sodium hypochlorite $(\mathrm{NaOCl})$ is used as the irrigant. ${ }^{5} \mathrm{NaOCl}$ is the most common root canal irrigant due to its tissue-dissolving capability, its broad antimicrobial action, as well as its ability to neutralize toxic products. ${ }^{6,7}$ However, $\mathrm{NaOCl}$ has many disadvantages, including cytotoxicity, reduced efficacy in the presence of organic matter, and interference with pulp regeneration procedures. ${ }^{8-10}$ These limitations stimulate the search for safer and more effective irrigants. An alternative to $\mathrm{NaOCl}$ is chlorhexidine digluconate $(\mathrm{CHX})$. This irrigant is a bisbiguanide disinfectant that has high antimicrobial activity, substantivity, and biocompatibility. However, CHX has been shown to have no tissue-dissolving activity and, when combined with $\mathrm{NaOCl}$, produces parachloroaniline, a toxic precipitate. ${ }^{11-13}$

The search for the ideal root canal irrigant revealed another candidate - alexidine (ALX). This substance is a bisbiguanide disinfectant similar to $\mathrm{CHX}$, it contains two hydrophobic ethylhexyl groups in its structure and it has a higher affinity for major bacterial virulence factors such as bacterial lipopolysaccharide and lipoteichoic acid than $\mathrm{CHX} .^{14,15}$ Alexidine is used as a disinfectant in contact lens solutions ${ }^{16,17}$ and as an antiseptic in mouthwashes. ${ }^{18-20}$ A recent study showed that the antibacterial activity of alexidine against $E$. faecalis infecting dentin blocks was superior to $\mathrm{CHX} .^{21}$ Also, while there are many reports of allergic reactions, including anaphylaxis, following exposure to chlorhexidine, there is a lack of reports for ALX. ${ }^{22-24}$ Another important advantage of alexidine is that its combination with $\mathrm{NaOCl}$ does not produce any precipitate or para-chloroaniline. ${ }^{25}$ Therefore, the combination of $\mathrm{NaOCl}$ as the main irrigant with $\mathrm{ALX}$ as the final irrigant may be of great utility for the treatment of endodontic infections.

The purpose of this study was to compare the efficacy of ALX alone or as a final irrigant in combination with $\mathrm{NaOCl}$ with the most common canal irrigants, $\mathrm{NaOCl}$, and chlorhexidine

\section{MATERIALS AND METHODS}

Preparation of dentin blocks

Forty-seven upper canines were obtained from the Tooth Bank of the Estácio de Sá University, Rio de Janeiro, RJ, Brazil. The teeth were extracted for orthodontic or prosthetic reasons. The study was approved by the Ethical Committee at Estácio de Sá University (approval number: 34551214.2.0000.5284). The coronals and the apical thirds of the teeth were removed using diamond disks (KG Sorensen Ind. Com. Ltda, Barueri,

${ }^{1}$ Estácio de Sá University, Endodontics 580, Alfredo Baltazar da Silveira, Rio de Janeiro, Brazil; ${ }^{2}$ Endodontics, Rio de Janeiro, Brazil; ${ }^{3}$ Microbiology, Rio de Janeiro, Brazil; ${ }^{4}$ Electronic Microscopy, Rio de Janeiro, Brazil and ${ }^{5}$ Department of Medical Microbiology, Institute of Microbiology, Rio de Janeiro, Brazil. 


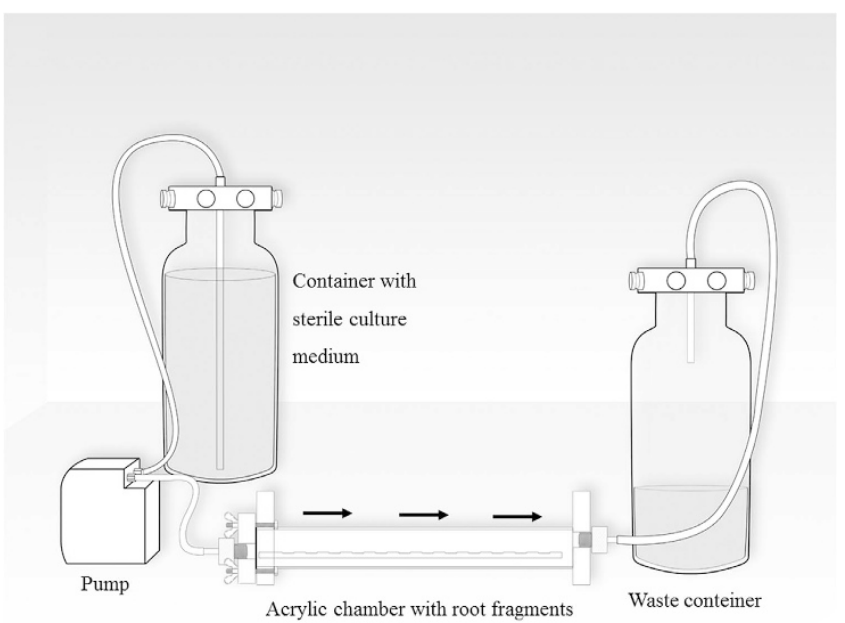

Figure 1. The apparatus used for bacteria incubation. Black arrows indicate the direction of the culture medium flow.

Brazil). Thereafter, the middle thirds of the roots were split along the long axis and cut into $25 \mathrm{~mm}^{2}$ fragments. The 94 specimens generated were immersed in $2.5 \% \mathrm{NaOCl}$ solution for $5 \mathrm{~min}$ and then in $17 \%$ EDTA (Biodinâmica, Ibiporã, PR, Brazil) for 5 min, followed by washing with $2.5 \%$ $\mathrm{NaOCl}$ for 5 min to remove the smear layer formed by the cutting action of the disks and any pulp tissue remaining. During these procedures, all solutions were agitated in an ultrasonic bath at a frequency of $50 \mathrm{~Hz}$ (Cristófoli, Campo Mourão, Brazil). Finally, the root fragments were washed with distilled water and sterilized by autoclaving.

\section{E. faecalis biofilm formation}

The root fragments were infected with E. faecalis (ATCC 29212) using an apparatus described by Luppens ${ }^{26}$ and specially adapted by the authors for the present study (Figure 1). The apparatus is composed of an acrylic chamber, a peristaltic pump (Exatta, Palhoça, SC, Brazil) and two 9-liter glass containers. The three components were connected by silicone tubing to have a constant flow of the culture medium. All components and supports were cleaned with $70 \%$ ethanol and autoclaved before use.

Before inoculation, the cementum surfaces of the 94 root fragments were bonded onto the internal acrylic base of the apparatus. Afterwards, the medium Tryptic Soy Broth (TSB, Difco, Detroit, USA) supplemented with $10 \%$ glucose (Merck, Whitehouse Station, USA). was pumped through the system for $30 \mathrm{~min}$ after which it was removed. Then a $24 \mathrm{~h}$ culture $(20 \mathrm{ml})$ of $E$. faecalis was introduced into the device and was maintained in contact with the root fragments for $30 \mathrm{~min}$. After this period, the pump was restarted, and samples were allowed to develop biofilm for $24 \mathrm{~h}$ at $37^{\circ}$ $C$ in the presence of a constant TSB flow of $6.25 \mathrm{ml} / \mathrm{min}$. At the end of this $24 \mathrm{~h}$ period, the root fragments were removed from the device and placed into cell culture wells (1 dentin block per well) of a 24-well plate (Nest Biotechnology, Wuxi, China). The manipulation of root fragments during the experiment was performed aseptically in a laminar flow hood (Nuaire, Plymouth, MN, USA). The quality control of the materials sterilization process was attested by the Institutional Sterilization Center.

Two samples were used to confirm the biofilm formation. On removal from the device, they were immediately fixed in freshly prepared $2 \%$ glutaraldehyde (Merck, Whitehouse Station, NJ, USA) and then dried in ascending ethanol concentrations. They were then dehydrated to their critical point in $\mathrm{CO}_{2}$ and sputter-coated with gold under vacuum and analyzed in a scanning electronic microscope at $10.00 \mathrm{Kv}$ and at 5000 magnification (Inspect F-50, FEl, Hillsboro, OR, USA).

\section{Dentin disinfection assay}

The root fragments were divided randomly into 4 groups ( $\mathrm{NaOCl}, \mathrm{CHX}, \mathrm{ALX}$ and $\mathrm{NaOCl}+\mathrm{ALX}$ ) of 20 blocks each and 12 samples were separated for the control group. The root fragments of the $\mathrm{NaOCl}, \mathrm{CHX}$, and ALX groups were immersed in $1 \mathrm{ml}$ of $2.5 \% \mathrm{NaOCl}, 2 \% \mathrm{CHX}$ and $1 \%$ ALX for $10 \mathrm{~min}$, respectively. The $1 \%$ solution of ALX was prepared by dissolving ALX dihydrochloride powder (Sigma-Aldrich, St Louis, MO, USA) in sterile distilled water $(1 \mathrm{~g} / 100 \mathrm{ml})$. The samples of the $\mathrm{NaOCl}+\mathrm{ALX}$ group were immersed in $1 \mathrm{ml}$ of $2.5 \% \mathrm{NaOCl}$ for $10 \mathrm{~min}$ followed by $1 \%$ ALX for $10 \mathrm{~min}$.

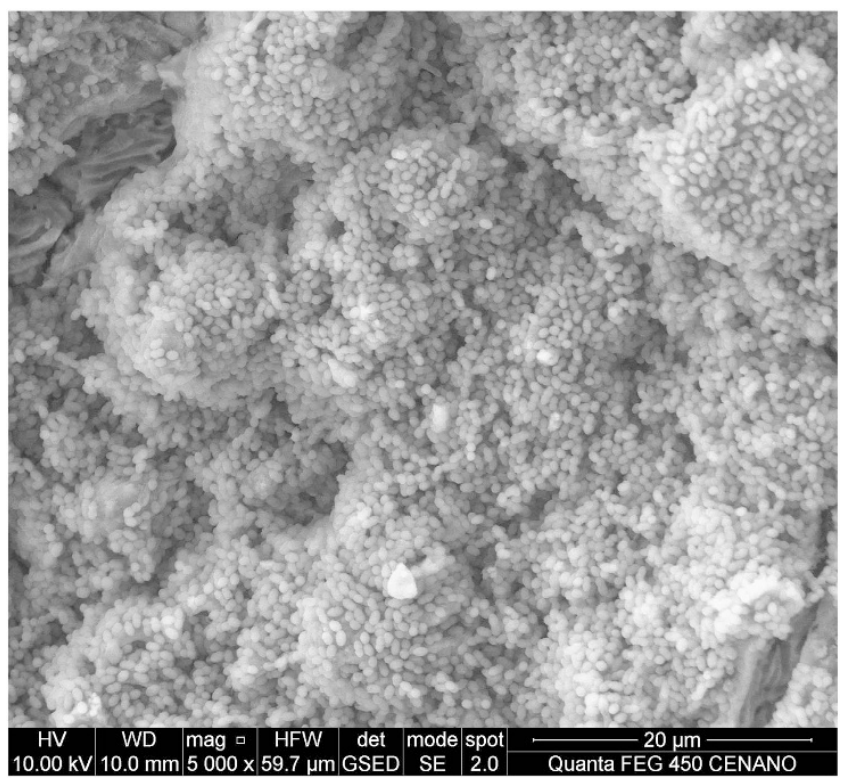

Figure 2. SEM image of a dentin block infected with $E$. faecalis biofilm.

In all groups, except the control group, a neutralizer solution was used for 5 min after the action of the irrigants. This solution was composed of $3 \%$ Tween $80,0.3 \%$ lecithin, $0.1 \%$ histidine and $0.5 \%$ sodium thiosulfate. In the control group, the root fragments were immersed in $1 \mathrm{ml}$ of sterile saline for $10 \mathrm{~min}$.

Microbial samples were obtained from root fragments by agitation in ultrasound for $3 \mathrm{~min}$. Tenfold serial dilutions were carried out in saline. Then, aliquots of $20 \mu \mathrm{l}$ of each dilution were plated onto Mitis-Salivarius agar (Difco, Detroit, MI, USA) plates, and incubated at $37^{\circ} \mathrm{C}$ for $24 \mathrm{~h}$. The colony-forming units (CFU) that grew were counted and then transformed into actual counts based on the known dilution factors.

Bacterial counts were analyzed via Kruskal-Wallis and Mann-Whitney tests. The significance level was established at $P<0.05$. The statistical analysis was performed using SPSS 17.0 computer software (IBM, New York, NY, USA).

\section{RESULTS}

An E. faecalis biofilm was observed by electron microscopy on both fragments analyzed (Figure 2). Intergroup analysis revealed no significant difference among the experimental groups $(P>0.05)$ except for the comparisons $C H X$ versus ALX, and $\mathrm{NaOCl}+\mathrm{ALX}$ versus $\mathrm{ALX}(P=0.004)$. ALX alone was the less effective irrigant. $\mathrm{CHX}$ and $\mathrm{NaOCl}+\mathrm{ALX}$ eradicated all bacterial cells in all samples. The $\mathrm{NaOCl}$ group showed bacterial growth only in one of the 20 samples while ALX showed bacterial growth in seven of the 20 samples (Table 1). All experimental groups were significantly more effective than the control group $(P<0.05)$.

\section{DISCUSSION}

Biomechanical cleaning with files and antibacterial irrigants reduces the bacteria load in infected root canals; however, microbial communities grown in biofilms are remarkably difficult to eradicate with antimicrobial agents. ${ }^{27}$ There are reports showing that microorganisms grown in biofilms could be 1000-1500 times more resistant to antimicrobials than planktonically grown bacteria. ${ }^{27,28}$ This in vitro study compared the antibacterial effect of ALX, a promising root canal irrigant, alone or as a final irrigant in combination with $\mathrm{NaOCl}$, with the most common root canal irrigants: $\mathrm{NaOCl}$ and $\mathrm{CHX}$.

$E$. faecalis was chosen as a bacterial marker since its resistance to many intracanal disinfectants is well documented ${ }^{2,4,29,30}$ Gram-positive facultative anaerobe bacterium is commonly found 
Table 1. Enterococcus faecalis counts after treatment with the tested irrigants

\begin{tabular}{llcccc}
\hline Groups & $N$ & Samples showing growth & Median & Mean & Range \\
\hline $2.5 \% \mathrm{NaOCl}$ & 20 & 1 & 0 & $0.8 \times 10$ & 0 \\
$2 \% \mathrm{CHX}$ & 20 & 0 & 0 & 0 & 0 \\
$1 \% \mathrm{ALX}$ & 20 & 7 & 0 & $1.94 \times 10^{2}$ & $0-1.25 \times 10^{3}$ \\
$2.5 \% \mathrm{NaOCl}+1 \%$ ALX & 20 & 0 & 0 & 0 & 0 \\
Saline & 12 & 12 & $4.25 \times 10^{4}$ & $8.96 \times 10^{4}$ & $2.05 \times 10^{2}-4.40 \times 10^{5}$ \\
\hline Abbreviation: CFU, colony-forming units. & & & & \\
\hline
\end{tabular}

in endodontically treated root canals that failed ${ }^{2}$. The persistence of $E$. faecalis may stem, in part, from its ability to form biofilms in root canals and its capability to invade dentinal tubules. ${ }^{31,32}$ Additionally, this bacterium possesses a plethora of virulence factors, highlighting: aggregation substances, surface adhesins, sex pheromones, lipoteichoic acid, extracellular superoxide, gelatinase, hyaluronidase, and cytolysin (hemolysin). ${ }^{4}$

In the present study, the inoculation apparatus allowed the formation of the biofilm under a slow turbulent flow to facilitate the adhesion of cells. When a tooth undergoes pulpal necrosis and subsequently develops periradicular periodontitis, exudates may cycle in and out of the canal. However, the exact flow rate that occurs in vivo has not been determined. This fluid exchange provides proteins, glycoproteins and other nutrients to the bacteria growing as a biofilm. This not only provides a sustainable nutrient source but also exerts a shear force on the bacterial biofilm. ${ }^{33}$

Contrary to expectations ALX alone was the less effective irrigant, but its combination with $\mathrm{NaOCl}$ was similar to $\mathrm{CHX}$. Two previous studies compared the antibacterial activity of ALX and $\mathrm{CHX}$, in the same concentration, and neither study found any significant difference. The first tested the canal irrigants against $E$. faecalis infected bovine dentin ${ }^{34}$ and the second compared these irrigants against Streptococcus mutans biofilm cultivated on human dentin blocks. ${ }^{35}$ Methodological differences such as the substrate and the bacterium tested could have influenced these results. Contrary to these results, another study ${ }^{21}$ found a better antibacterial substantivity against $E$. faecalis using $1 \%$ ALX in comparison to $2 \% \mathrm{CHX}$. However, it is important to emphasize that in this substantivity assay, the antimicrobial action was evaluated over a period of 80 days. Also, the dentin fragments were immersed in the antimicrobial solution first and after transferred to the bacterial suspension, which is the opposite sequence from the other studies. In the present and previous studies, the antibacterial action was analyzed only once, immediately after the irrigant contact time.

The results from the present study are in accordance with a recent study ${ }^{36}$, which found that $5.25 \% \mathrm{NaOCl}$ was highly effective against $E$. faecalis compared with $\mathrm{CHX}$ and ALX. There was no significant difference between 1\% ALX and 2\% CHX. Despite both studies used different concentrations of $\mathrm{NaOCl}$, it is not expected significant differences in the antimicrobial activity of $\mathrm{NaOCl}$ varying its concentration. ${ }^{37-39}$

The best results were obtained with $2 \% \mathrm{CHX}$ and with the combination of $2.5 \% \mathrm{NaOCl}+1 \% \mathrm{ALX}$ as a final irrigant. In fact, both substances completely destroyed the bacterial biofilms. However, $\mathrm{CHX}$ in not able to dissolve organic tissues. Thus, the combination of $\mathrm{NaOCl}+\mathrm{ALX}$ has a good potential for endodontic treatment to eliminate biofilms: the solvent capability of $\mathrm{NaOCl}$, the high biocompatibility of ALX, the advantage that it does not form any precipitate when in combination with $\mathrm{NaOCl}$ and now, the confirmed antibacterial efficacy of the tested protocol, compatible with $\mathrm{CHX}$ and $\mathrm{NaOCl}$ alone, justify this potential. However, it is important to highlight that the group $\mathrm{NaOCl}+\mathrm{ALX}$ was privileged by a higher contact time between the root fragments and irrigant solutions (20 min) in comparison with the other groups (10 min). This difference was necessary since ALX was used in this group as a final irrigant. Certainly, further studies are required to compare this final irrigation protocol with others.

Under the conditions of the present study, it was concluded that $1 \%$ ALX alone should not be indicated as an intracanal irrigant since its antibacterial effect against $E$. faecalis was inferior to $2 \% \mathrm{CHX}$ and $2.5 \% \mathrm{NaOCl}$. However, the combination of $\mathrm{NaOCl}$ with ALX as a final irrigant has potential to be used in endodontic treatment to eliminate biofilms.

\section{ACKNOWLEDGEMENTS}

This study was supported by grants from Fundação de Amparo à Pesquisa do Estado do Rio de Janeiro (FAPERJ), a Brazilian Governmental Institution.

\section{COMPETING INTERESTS}

The authors declare no conflict of interest.

\section{REFERENCES}

1 Siqueira JF Jr., Rôças IN. Diversity of endodontic microbiota revisited. J Dent Res 2009; 88: 969-981.

2 Rôças IN, Siqueira JF Jr, Santos KR. Association of Enterococcus faecalis with different forms of periradicular diseases. J Endod 2004; 30: 315-320.

3 Ricucci D, Siqueira JF Jr. Biofilms and apical periodontitis: study of prevalence and association with clinical and histopathologic findings. J Endod 2010; 36: 1277-1288.

4 Kayaoglu G, Orstavik D. Virulence factors of Enterococcus faecalis: relationship to endodontic disease. Crit Rev Oral Biol Med 2004; 15: 308-320.

5 Rôças IN, Siqueira JF Jr. Comparison of the in vivo antimicrobial effectiveness of sodium hypochlorite and chlorhexidine used as root canal irrigants: a molecular microbiology study. J Endod 2011; 37: 143-150.

6 Zehnder M. Root canal irrigants. J Endod 2006; 32: 389-398.

7 Mohammadi Z. Sodium hypochlorite in endodontics: an update review. Int Dent $J$ 2008; 58: 329-341.

8 Pashley EL, Birdsong NL, Bowman K, Pashley DH Cytotoxic effects of $\mathrm{NaOCl}$ on vital tissue. J Endod 1985; 11: 525-528.

9 Pappen FG, Qian W, Aleksejuniene J, Leonardo Rde T, Leonardo MR, Haapasalo M. Inhibition of sodium hypochlorite antimicrobial activity in the presence of bovine serum albumin. J Endod 2010; 36: 268-271.

10 Fouad AF. The microbial challenge to pulp regeneration. Adv Dent Res 2011; 23: 285-289.

11 Carlson HC, Porter CK. Inhibitory effect of a synthetic antibiotic mouthwash (QR-711) on dental plaque and gingivitis in young adults. J Periodontol 1973; 44: 225-227.

12 Shen Y, Stojicic S, Haapasalo M. Antimicrobial efficacy of chlorhexidine against bacteria in biofilms at different stages of development. J Endod 2011; 37: 657-661.

13 Bernardi A, Teixeira CS. The properties of chlorhexidine and undesired effects of its use in endodontics. Quintessence Int 2015; 46: 575-582.

14 Zorko $M$, Jerala R. Alexidine and chlorhexidine bind to lipopolysaccharide and lipoteichoic acid and prevent cell activation by antibiotics. $J$ Antimicrob Chemother 2008; 62: 730-737.

15 McDonnell G, Russell AD. Antiseptics and disinfectants: activity, action, and resistance. Clin Microbiol Rev 1999; 12: 147-179. 
16 Yanai R, Ueda K, Nishida T, Toyohara M, Mori O. Effects of tonicity-adjusting and surfactant agents on the antimicrobial activity of alexidine. Eye Contact Lens 2011; 37: $57-60$.

17 Alizadeh H, Neelam S, Cavanagh HD. Amoebicidal activities of alexidine against 3 pathogenic strains of acanthamoeba. Eye Contact Lens 2009; 35: 1-5.

18 Eley BM. Antibacterial agents in the control of supragingival plaque--a review. $\mathrm{Br}$ Dent J 1999; 186: 286-296.

19 Muhlemann HR, Hulss D, Steiner E. Antimicrobial rinses and proximal plaque on removable gold crowns. Helv Odontol Acta 1973; 17: 89-95.

20 Weatherford TW 3rd, Finn SB, Jamison HC. Effects of an alexidine mouthwash on dental plaque and gingivitis in humans over a six-month period. J Am Dent Assoc 1977; 94: 528-536.

21 Barrios R, Ferrer-Luque CM, Arias-Moliz MT, Ruiz-Linares M, Bravo M, Baca P. Antimicrobial substantivity of alexidine and chlorhexidine in dentin. J Endod 2013; 39: $1413-1415$

22 Rutkowski K, Wagner A. Chlorhexidine: a new latex? Eur Urol 2015; 68: 345-347.

23 Hong CC, Wang SM, Nather A, Tan JH, Tay SH, Poon KH. Chlorhexidine anaphylaxis masquerading as septic shock. Int Arch Allergy Immunol 2015; 167: 16-20.

24 Sharp G, Green S, Rose M. Chlorhexidine-induced anaphylaxis in surgical patients: a review of the literature. ANZ J Surg 2016; 86: 237-243.

25 Kim HS, Zhu Q, Baek SH, Jung IY, Son WJ, Chang SW et al. Chemical interaction of alexidine and sodium hypochlorite. J Endod 2012; 38: 112-116.

26 Luppens SB, Reij MW, van der Heijden RW, Rombouts FM, Abee T. Development of a standard test to assess the resistance of Staphylococcus aureus biofilm cells to disinfectants. Appl Environ Microbiol 2002; 68: 4194-4200.

27 Svensäter G. Biofilms in endodontic infections. Endod Topics 2004; 9: 27-36.

28 Mohammadi Z, Palazzi F, Giardino L, Shalavi S. Microbial biofilms in endodontic infections: an update review. Biomed J 2013; 36: 59-70.

29 Kayaoglu G, Erten H, Bodrumlu E, Orstavik D. The resistance of collagen-associated, planktonic cells of Enterococcus faecalis to calcium hydroxide. J Endod 2009; 35: 46-49.

30 Kayaoglu G, Erten H, Orstavik D. Growth at high pH increases Enterococcus faecalis adhesion to collagen. Int Endod J 2005; 38: 389-396.

31 Love RM. Enterococcus faecalis--a mechanism for its role in endodontic failure. Int Endod J 2001; 34: 399-405.
32 Dunavant TR, Regan JD, Glickman GN, Solomon ES, Honeyman AL. Comparative evaluation of endodontic irrigants against Enterococcus faecalis biofilms. J Endod 2006; 32: 527-531.

33 Vieira MJ, Melo LF, Pinheiro MM. Biofilm formation: hydrodynamic effects on internal diffusion and structures. Biofouling 1993; 7: 67-80.

$34 \mathrm{Kim}$ HS, Woo Chang S, Baek SH, Han SH, Lee Y, Zhu Q et al. Antimicrobial effect of alexidine and chlorhexidine against Enterococcus faecalis infection. Int J Oral Sci 2013; 5: 26-31.

35 Ruiz-Linares M, Ferrer-Luque CM, Arias-Moliz T, de Castro P, Aguado B, Baca P Antimicrobial activity of alexidine, chlorhexidine and cetrimide against Streptococcus mutans biofilm. Ann Clin Microbiol Antimicrob 2014; 13: 41.

36 Bukhary S, Balto H. Antibacterial efficacy of octenisept, alexidine, chlorhexidine, and sodium hypochlorite against Enterococcus faecalis Biofilms. J Endod 2017; 43: 643-647.

37 Siqueira JF Jr., Rôças IN, Favieri A, Lima KC. Chemomechanical reduction of the bacterial population in the root canal after instrumentation and irrigation with 1\%, 2.5\%, and 5.25\% sodium hypochlorite. J Endod 2000; 26: 331-334.

38 Alves FR, Almeida BM, Neves MA, Rôças IN, Siqueira JF Jr. Time-dependent antibacterial effects of the self-adjusting file used with two sodium hypochlorite concentrations. J Endod 2011; 37: 1451-1455.

39 Bystrom A, Sundqvist G. The antibacterial action of sodium hypochlorite and EDTA in 60 cases of endodontic therapy. Int Endod J 1985; 18: 35-40.

This work is licensed under a Creative Commons Attribution 4.0 International License. The images or other third party material in this article are included in the article's Creative Commons license, unless indicated otherwise in the credit line; if the material is not included under the Creative Commons license, users will need to obtain permission from the license holder to reproduce the material. To view a copy of this license, visit http://creativecommons.org/licenses/ by/4.0/

(c) The Author(s) 2018 